\title{
Water Management in the Iberian Peninsula: New Solutions for Old Problems?
}

\author{
J.E. Fernández \\ Instituto de Recursos Naturales y \\ Agrobiología (IRNAS-CSIC) \\ Avenida de Reina Mercedes, 10 41012-Seville \\ Spain
}

\author{
M.I. Ferreira \\ DCEB \\ Instituto Superior de Agronomia (ISA) \\ Technical University of Lisbon \\ Tapada da Ajuda, 1349-017 Lisboa \\ Portugal
}

Keywords: irrigation, drought, sustainability, climate change

\begin{abstract}
The increasing demand of fresh water from different sectors puts pressure in scientists and engineers to develop more effective ways of using the available water resources. In Spain and Portugal, countries of Mediterranean climate with hot and dry summers, the allocation of water resources is especially controversial. This emphasises the need for a rational use of water. We present features and recent developments of Spanish and Portuguese water policies and some consequences on the use of land and water. We consider how social, economic and environmental problems might evolve in the expected scenarios of population growth and climatic change, and analyse the response from the scientific community to the new challenges. Finally, we pointed out that the combined efforts of professionals and users provide useful tools for satisfying the consumers demand at the same time that the environmental footprint is minimized.
\end{abstract}

\section{THE NEED FOR A SUSTAINABLE USE OF WATER}

The Green Revolution (Mexico, 1943) was a step ahead on the production of foodrelated agricultural products. The approach, based on a massive use of pesticides, synthetic fertilizers, improved crop varieties and irrigation, led to several decades of continuous increase in crop production and food availability. It caused, however, severe problems related to soil erosion and contamination, aquifers depletion, greenhouse gas emissions and loss of biodiversity. To minimize these problems, a variety of sustainable agricultural management practices were developed, including conservation tillage, deficit irrigation strategies and biological control of pests. However, both the increase in population and the expected climate scenarios push for even more efficient agricultural practices.

One of the key aspects of sustainable agricultural management is water. In 1950, when less than $3 \times 10^{9}$ people live in our planet, the available fresh water per capita was $12050 \mathrm{~m}^{3}$. At present, the global population is ca. $7 \times 10^{9}$ people, being the fresh water per capita around $6000 \mathrm{~m}^{3}$. In 2050 , it is expected a population of ca. $10 \times 10^{9}$ people, with some $4580 \mathrm{~m}^{3}$ of fresh water per capita (National Geographic, April 2010). Over 70\% of the world freshwater resources are currently consumed in agricultural practices, and this number increases to more than $80 \%$ in arid and semi-arid countries (FAO, 2002). It is not surprising, therefore, the existence of an increasing pressure from different sectors for a more sustainable use of water in agriculture. Now, should we put all the blame in agriculture? The virtual water concept, first defined in the early 1990s by Tony Allan (King's College, London) could help to answer this question. Table I shows the amounts of water consumed in the production of several vegetable and meat products. The table clearly shows that it is much more expensive, in terms of water consumption, to produce meat food than vegetable food. But the improvement of the living conditions in many countries, especially some highly-populated Asian countries such as India and China, is yielding to an increasing demand for meat-related products. So it seems that changes in the consumer's habits are partly responsible for the high amounts of water consumed in the production of food. And the lack of water is not the only problem. In terms of water 
distribution, it is expected that in 2030 , some $20 \%$ of the world population $\left(1.8 \times 10^{9}\right.$ people out of the expected $9 \times 10^{9}$ ) will live in regions of severe water scarcity. In addition, agriculture is intensive in areas with high temperature and radiation levels in summer, such as many areas of Mediterranean climate. The problem is that, when winter precipitation is not enough, water shortages in those areas are leading to unacceptable levels of salt accumulation in the soil (Tóth et al., 2008).

\section{NOTES ON WATER AVAILABILITY VERSUS WATER DEMAND IN IBERIA}

The mentioned problems occur in Spain and Portugal, together with some others. About $70 \%$ of the annual precipitation collected in most areas of continental Portugal and Spain fall in six months (Autumn/Winter), with a sinusoidal pattern, being very low when reference evapotranspiration (ETo), and therefore the crop water requirements, are higher.

Spain is the most arid country in the European Union (EU) as even if the average precipitation is equivalent to $85 \%$ of that in the $\mathrm{EU}$, the greatest values of $\mathrm{ET}_{\mathrm{o}}$ (López et al., 2008) introduce a strong disequilibrium between offer and demand.

Portugal, like Spain, is dominated by temperate climate of Mediterranean type. According to Reis and Gonçalves (1981) and IM (2008, www.meteo.pt), we find humid mesothermic with dry hot summer (Csa, Köppen classification) in some areas of Portugal, cool-summer Mediterranean climate (Csb) with Atlantic influence in others, and, in the SE, also a transition to a cold semi-arid climate, with hot and dry summer and cold winters (BSk), also called steppe climate (Kottek et al., 2006). The spatial heterogeneity of precipitation is extremely high in Iberian countries. As an example, in Portugal, the average yearly precipitation (in average $960 \mathrm{~mm}$, INAG, 2004) ranges from $>2800 \mathrm{~mm}$ in $\mathrm{NW}$ of the country (or some areas of the Madeira and Azores islands) to $<600 \mathrm{~mm}$ in the South (Fig. 1a), with almost inverse relationship with the average temperature distribution which ranges from $5.4^{\circ} \mathrm{C}$ (winter) to $18.0^{\circ} \mathrm{C}$ (summer) with important daily amplitudes.

The relationship between total water availability and water demand for human uses (excluding ecosystem services) is in average 5.3 in Portugal (75 in NW to 0.7 in the Southern coast), with only a few areas where the value is below 1 , according to http://www.inag.pt/inag2004/port/a_intervencao/planeamento/pna/pdf_pna_v1/v1_c2_t05 .pdf, where a description on water resources issues can be found (in Plaño Nacional da Agua). However, this reflects that the restrictions in available water in the interior and in the south, together with the very poor soils in those areas, have been historically limiting the economical activities, especially in agriculture. In Portugal, the water availability seams to contribute to explain statistically the asymmetries in population density (Fig. 1b). This statement seems to be valid for SW Europe, i.e. Iberia (with the exception of areas with high touristic pressure, in the Southern coast) as well as for SE Europe (such as Greece). In fact, the average number of inhabitants $/ \mathrm{km}^{2}$ in Portugal (Fig. 1b) and Spain (109 and 88, respectively, for 2002) or even Greece, is much lower than the European average (in the driest areas of Portugal, as low as 7 inhabitants $/ \mathrm{km}^{2}$ ).

The soil quality is also related with hydrology. The excess of winter rainfall in conditions of sloppy terrain, leads in many Portuguese areas to very high yearly water losses by runoff, which are $385 \mathrm{~mm}$ (INAG, 2004) on average for Portugal (and $223 \mathrm{~mm}$ for Spain) with severe potential losses, not only of water, but of soil. This steepness and consequent high erosion hazard largely contributes to explain the extreme shallow soils in increasing larger areas of the country. Soil erosion is a serious problem in Portugal despite the fact that $67 \%$ of the land is covered by woody plants, mainly forests. In such sloppy areas, where agriculture and forestry were traditionally combined in Portugal, the absence of protection from vegetation (obstacles and sinks to water progression) has been related with summer forest wildfires (Ferreira et al., 2005) and the dramatic abandon of agriculture (and population) in last decades (FAOSTAT, 1998), leading to erosion processes severely aggravated. In North-Central Portugal, soil losses after fire were four orders of magnitude $\left(10^{4}\right)$ higher than for "mature" sites (Shakesby et al., 1993). Furthermore, that implies important loss of biodiversity exactly where the higher nature value farmland per country in Europe could be found (EEA, 2004). 
Besides the aspects referred above, frequent cycles of drought (Fig. 2) make more difficult to ensure stable water sources for every area of these countries.

\section{WATER MANAGEMENT POLICIES AND FIRST CONSEQUENCES}

Tensions between different social and productive sectors in Iberian countries, originated by increasing demand for water, are common. These are derived both from the spatio-temporal variability of the available water resources, and from the developments occurred in last decades. Portugal and Spain, members of the EU since 1986, were bound to follow the EU Water Framework Directive (WFD) (Directive 2000/60/EC). The aim of the WFD is to reach a good ecological and chemical status of all water bodies (groundwater, surface, coastal and transitional) by 2015.

To meet this goal, Spain developed the program AGUA, or Actions for the Management and Use of Water (Spanish Ministry of Environment, 2004), an additional water policy based on the principles of the WFD. Spanish authorities reacted by developing and applying, from the end of the XX century, more efficient water policies. The Sanitation and Purification Plan (Spanish Ministry of Environment, 1995), The National Plan on Irrigation (1996), The White Book of Water (Spanish Ministry of Environment, 1998) and The National Plan on Irrigation (1998) are some examples.

In Portugal, following the EU WFD, a reference should be made to the update of the previously existing (2000) River Basin Management Plans (Planos de Gestão de Bacia Hidrográfica), the update of the previous Plano Nacional da Água (2002), and the International River Basin Plans (Plano de Bacia Internacional, to be built/in progress).

The National Plan for the Efficient Use of Water (PNUEA, which implementation at local scale has been determined by law the $26^{\text {th }}$ January 2011), the integration actions between the National Authority for Water (Instituto da Água, INAG, http://www.inag.pt/) and the River Basin Administration (ARH) with active public participation (http://ec.europa.eu/environment/water/participation/pdf/eurobarometer_report.pdf)

defining a list of special so-called Significant Questions (QSIGA, e.g. http://www.cadcalbufeira.org/doc/pt/PT9 9.pdf), the Program for Vulnerable Zones (Programa de Acção da Zona Vulnerável) to prevent eutrophication of superficial water and contamination of underground water (cf http://dre.pt/pdf1sdip/2010/02/02800/0038000392.pdf), are examples of the many other actions that followed, which interaction is too complex.

Some progress was made under the frames of these water policy regulations. Some of the most significant changes made in the last decades, in Spain, are the following:

1) Improvements in hydraulic infrastructures. No more than 60 dams were working in Spain in 1900. In 1950 the number was 270, over 1000 in the year 2000 and more than 1200 in 2010. The dams have avoided to a great extent water shortages in the dry seasons, but are not the only new structures allowing for that. A significant number of regulating ponds have also been built, which storage water from rivers and channels. In addition, many kilometres of open channels have been substituted by pipes, avoiding water losses by evaporation, infiltration and leaks, which in many cases amounted to $40 \%$ of the transported water.

2) Water price increase. The use of pipes had an additional and crucial advantage: it allowed for the use of water meters. In the old days each farmer paid a fixed amount of money, independently of the amount of water derived to the farm in each irrigation event. With the water meters the growers have to pay for the amount of water they used, an efficient method of increasing their awareness on water being a precious resource. This was accompanied by an increase in the price of water (Table 2). In fact, $70 \%$ of the mentioned improvements in the Spanish hydraulic network were financed up by the EU, but the rest has to be paid by the growers, through the increase in the price of water.

3) New agricultural practices. In Spain, just a couple of decades ago, cotton, corn and sugar beet, among other widely cropped species, were fully irrigated. Irrigation requirements amounted easily to $8000 \mathrm{~m}^{3} \mathrm{ha}^{-1} \mathrm{yr}^{-1}$. Nowadays, all these crops are deficit irrigated in Spain, with irrigation amounts below $4000 \mathrm{~m}^{3} \mathrm{ha}^{-1} \mathrm{yr}^{-1}$. In addition, 
there has been a significant shift to less water-demanding crops, such as grapevine, olive and almond trees, for which irrigation amounts range from 1500 to $3000 \mathrm{~m}^{3} \mathrm{ha}^{-1}$ $\mathrm{yr}^{-1}$. In addition, localised irrigation is becoming widely used, in detriment of gravity and other less efficient irrigation methods (Fig. 3). The time evolution of the price of water in recent years is one of the main reasons for both the shifting to less waterdemanding crops and the increase of localised irrigation. Table 2 shows that, for a crop consuming $4000 \mathrm{~m}^{3} / \mathrm{ha}$, the price of water for irrigation increased from some $100 € \mathrm{ha}^{-1}$ in the $1990 \mathrm{~s}$ to $220 € /$ ha today. If we take into account the price of the energy for pumping water, the cost is $360 € \mathrm{ha}^{-1}$. And, in areas were water is coming from recently built dams under new price regulations, the cost can be as high as $540 € \mathrm{ha}^{-1}$.

4) Non-conventional water resources. One of the WFD policies is that all towns with over 2000 inhabitants must purify their wastewater. Aimed at 2015, this policy has driven the construction of many purification plants in Spain. Also, the current national government has pushed the construction of plants for desalinizing marine and brackish water. The use of these, however, is curtailed by high energy consumption and contamination problems. They produce, in fact, a very expensive water $\left(0.60 € \mathrm{~m}^{-3}\right)$, yet they are used to provide water to the most arid regions in years of low rainfall. The use of non-conventional water resources for irrigation is also a possibility to explore but there are still many unknowns. Currently, it amounts to ca. $1 \%$ of the available water resources.

The described achievements cover the demand in most Spanish regions, except in a reduced number of regions like Murcia and Almeria. These are arid regions in which annual precipitation is rarely over $250 \mathrm{~mm}$, and which have undergone a very fast growth both in agriculture and tourism. Both circumstances mean a big demand for water resources. While the yearly water needs for irrigation in Spain are $\approx 22000 \mathrm{hm}^{3}$, the total water capacity of dams is $55602 \mathrm{hm}^{3}$ (17 389 hydroelectric + 38213 others). Although, maximum capacity is rarely achieved: in August 2009 the Spanish dams were at $54 \%$ of their maximum capacity, figure that increases to $81 \%$ in August 2010. Groundwater extraction amounts to $5500 \mathrm{hm}^{3}$ and purified desalinized water makes some $200 \mathrm{hm}^{3}$.

In Portugal, what was described above applies to some differences or nuances. Concerning irrigation, some important facts are:

1) Improvements in hydraulic infrastructures. Changes to note were (a) the rehabilitation of old irrigation projects (with at least 40 years) which are now operating very well, with full control of flow and transport time; in fact, all of these irrigation networks have structures of remote control and record, all are impermeable, even for traditional irrigation (gravity) so that transport efficiency became excellent, (b) a new irrigation project, Alqueva dam and correspondent irrigated area, which deserves a special reference as the biggest artificial lake in Europe, located in a largest area threatened by desertification, near the Portuguese-Spanish border. The total area of irrigation projects is: 173777 ha infrastructured, 266935 ha of total project area (Autoridade Nacional do Regadio, http://sir.dgadr.pt/exp_infra). The dams in the Center and South generally have a capacity for two years of inter-annual regularization, while in the North the regularization is generally intra annual or there is no need for regularization (NW).

2) Water price increase. Water meters are a tradition in many irrigation projects. All users pay water but prices are quite low. In fact, water savings have been more related with saving energy and changing irrigation systems then changing price. The price for water comprises now five components (A, E, I, O and U: the volume, the level of contamination, the occupation of hydric domain, a tax for water resources scarcity, etc, as defined by the national system on water resources uses (SNITURH, http://www.inag.pt/sniturh_guias/DOCS/PUBLICO/Guia_Legislacao_06Maio2011)

3) New agricultural practices. As in Spain, an important transition from traditional to pressurized/localized irrigation (and fertirrigation) was observed, both in public irrigation projects and private. However, in Portugal, there was (1) an abandon of agricultural land extremely important since 1986, converting partially to forest and (2) a change from rainfed orchards to irrigated, in intensive production even if same 
species. Even if those are less water-demanding crops, such as grapevine and olive groves, this and a clear shift to the South give a projection of increase in water demand.

Non-conventional water resources have no expression in Portugal.

Concerning quality, two regions have problems of salinization (Setúbal Peninsula and Algarve) and a few vulnerable areas report agrochemical contamination, mainly nitrogen. The quantity and quality of the water arriving in the three international rivers is also a reason of preoccupation.

Last developments ensured that $100 \%$ of the population has domestic access to water treated and to sewer services, closely controlled by the Entidade Reguladora dos Serviços de Aguas e Resíduos (http://www.ersar.pt/website/). Important progresses concerned entrepreneur management, security plans, transport losses, etc. A strategically decision, implemented, is the shift of water uses from underground to superficial water, being underground water a strategic reserve for direct human consumption.

\section{UNCERTAINTIES}

It seems, therefore, that even in countries like Spain and Portugal, with high spatio-temporal variability in rainfall and an increasing demand from different sectors, which have boomed in the last decades, good quality water supply can be ensured provided adequate policies are followed. Still, there are some sources of uncertainty which have to be considered from now, before serious problems develop. Thus, the development of tourism and new agricultural practices in many Mediterranean areas with poor water resources are aggravating the problems derived from the lack of water. Climate scenarios foreseen for the Iberian Peninsula show an increase in temperature and a reduction in rainfall. Considering that a rise of $1{ }^{\circ} \mathrm{C}$ in the average temperature, together with $5 \%$ decrease in average precipitation would lead to $20 \%$ decline in collected water, expected climate changes should be seriously taken into account. Water quality deterioration, due to either salt intrusion or irresponsible use of agrochemicals is another problem. In addition, there are uncertainties derived from changes in legal policies regulating agricultural subsidies and competences of national vs. regional governments. Water transfers between basins could minimize water shortages in some regions. However, not always they are well accepted by governments. The improvement of the link between the policies and the research results could help to support such decisions.

\section{SCIENTIFIC DEVELOPMENT AND CONSUMER'S AWARENESS}

The scientific community is constantly developing potential solutions for a more rational use of water in agriculture. This allow us to be hopeful on the development of strategies and techniques efficient enough for the mentioned uncertainties to vanish or, at least, to reduce the related risks. Thus, localised irrigation is considered by many as a keystone for water saving and control of irrigation. Combined with deficit irrigation strategies, it allows for considerable water savings with minimum yield reductions. Increasing knowledge on crop ecophysiology is behind the development of more efficient DI strategies (Morison et al., 2008). New methods for accurate measurement of crop water needs, making possible a more appropriate estimation of irrigation depths as well as more convenient water stress indicators such as leaf turgor pressure, trunk diameter variations and electrical potential, have been the object of a significant amount of work in the last decades. The new sensors, possibly combined with remote imagery, could allow for precise irrigation even in big farms with high soil and crop variability. We can also outline the potential of new plant breeding and molecular biology techniques in obtaining genetically modified (GM) varieties able to keep high yields in conditions of severe water shortages thought this can be questionable due to associated risks. It is also true, however, that EU regulations limits to a great extend the use of GM crops in European countries. All this technical and scientific achievements, together with the increase in the price of water for agricultural use, has led to a significant change in the producers' goal: maximum productivity, instead of maximum production, is now pursued (Fig. 4). Besides 
scientific achievements, consumers are increasingly aware of the need for water saving. A symbolic but not irrelevant movement concerning public awareness is related with urban horticulture and/or proper management of water in cities, either increasing cities resilience or replacing high consuming grass in city parks and gardens by low consuming species. Furthermore, the demand for labelling that ecoverifies a rational environmental footprint of food products is increasing.

\section{CONCLUSIONS}

Water management in agriculture faces problems of increasing severity, due to population growth, development of other sectors competing for water, and the need for preserving the environment. The joint efforts of scientists, engineers, producers and consumers could led to more rational ways of using water, but the challenge is huge. According to some prospects, the population in our planet is going to increase $50 \%$ in the next 40 years, a period in which an increasing lack of water is expected in many productive areas, due to climate change. It is the responsibility of all of us to find new ways of using water resources focussed to satisfying not only our demands, but also those of future generations.

\section{ACKNOWLEDGEMENTS}

The authors want to acknowledge Juan Saura, from the Confederación Hidrográfica del Guadalquivir, José Roldán, from the University of Córdoba, and Elías Fereres, from the University of Córdoba and the Spanish National Research Council, as well as Rui Fernando, from Instituto Superior de Agronomia (UTLisbon) for providing us with valuable material for doing this work.

\section{Literature Cited}

Besset, J., Génard, M., Girard, T., Serra, V. and Bussi, C. 2001. Effect of water stress applied during the final stage of rapid growth on peach trees (cv. Big-Top). Sci. Hort. 91:289-303.

Directive 2000/60/EC. 2000. Directive of the European Parliament and of the Council of $23^{\text {rd }}$ October 2000, establishing a framework for Community action in the field of water policy.

FAO. 2002. La agricultura mundial: hacia los años 2015-2030. Food and agriculture organization of the United Nations. FAO. Rome, Italy.

FAOSTAT Agricultural data 1998 - http://apps.fao.org/page/collections?subset= agriculture access in 2004.

Ferreira, A.J.D., Coelho, C.O.A., Boulet, A.K. and Lopes, F.P. 2005. Temporal patterns of solute loss following wildfires in central Portugal. International Journal of Wildland Fire 14(4):401-412.

López, C., Martín, I. and Alcácer, C. 2008. Water policy in Spain: A portrait. Options Mediterranéennes 83:45-53.

Morison, J.I.L., Baker, N.R., Mullineaux, P.M. and Davies, W.J. 2008. Improving water use in crop production. Phil. Trans. R. Soc. B 363:639-658.

Rego, F. 1992. Land use changes and wildfires. In: Responses of Forest Ecosystems to Environmental Changes. In: A. Teller, P. Mathy, and J.N.F Jeffers (eds.), Elsevier Applied Science, London, p.367-373.

Shakesby, R.A., Coelho, C.D.A., Ferreira, A.D., Terry, J.P. and Walsh, R.P.D. 1993. Wildfire impacts on soil erosion and hydrology in wet Mediterranean forest, Portugal. International Journal of Wildland Fire 3(2):95-110.

Spanish Ministry of Environment. 1995. Plan de Saneamiento y Depuración 1995-2005 (Sanitation and Purification Plan 1995-2005). Madrid.

Spanish Ministry of Environment. 2004. Programa AGUA (Water Program). Actuaciones para la gestión y utilización del agua. Madrid. 
$\underline{\text { Tables }}$

Table 1. Virtual water needed for producing vegetable and meat products.

\begin{tabular}{cc} 
Water needed for producing $1 \mathrm{~kg}$ of product in average $(\mathrm{L})$ \\
\hline 909 & Corn \\
359 & Beans \\
255 & Potatoes \\
15,497 & Beef \\
6,309 & Pork \\
3,918 & Chicken \\
\hline
\end{tabular}

Table 2. Price of water for agricultural use in Spain. The prices before and after the improvements in the hydraulic network described in Section 2 are shown, as well as the price including energy for pumping and the prices of water coming from the most recently built dams, which are under new price regulations.

\begin{tabular}{ll}
\hline \multicolumn{2}{c}{ Price of water $\left(€ \mathrm{~m}^{-3}\right)$} \\
\hline Before the improvements & $0.02-0.03$ \\
After the improvements & $0.05-0.06$ \\
Including energy & 0.09 \\
Water from new dams & $0.12-0.15$ \\
\hline
\end{tabular}




\section{Figures}
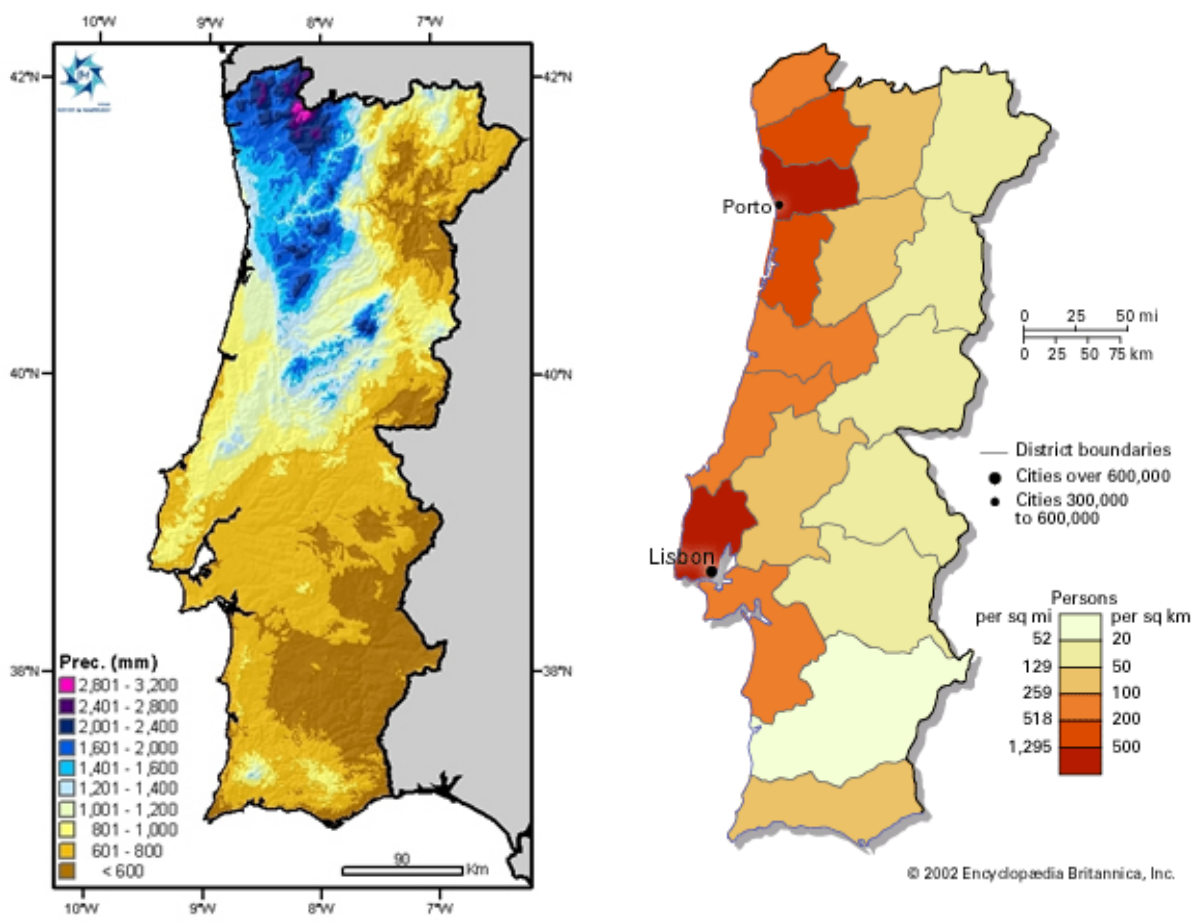

Fig. 1. Average yearly precipitation distributions and population density of Portugal: water availability (a) explains partially the asymmetries in population density (b). Sources: Instituto de Meteorologia (www.meteo.pt) and Encyclopcedia Britannica Online.

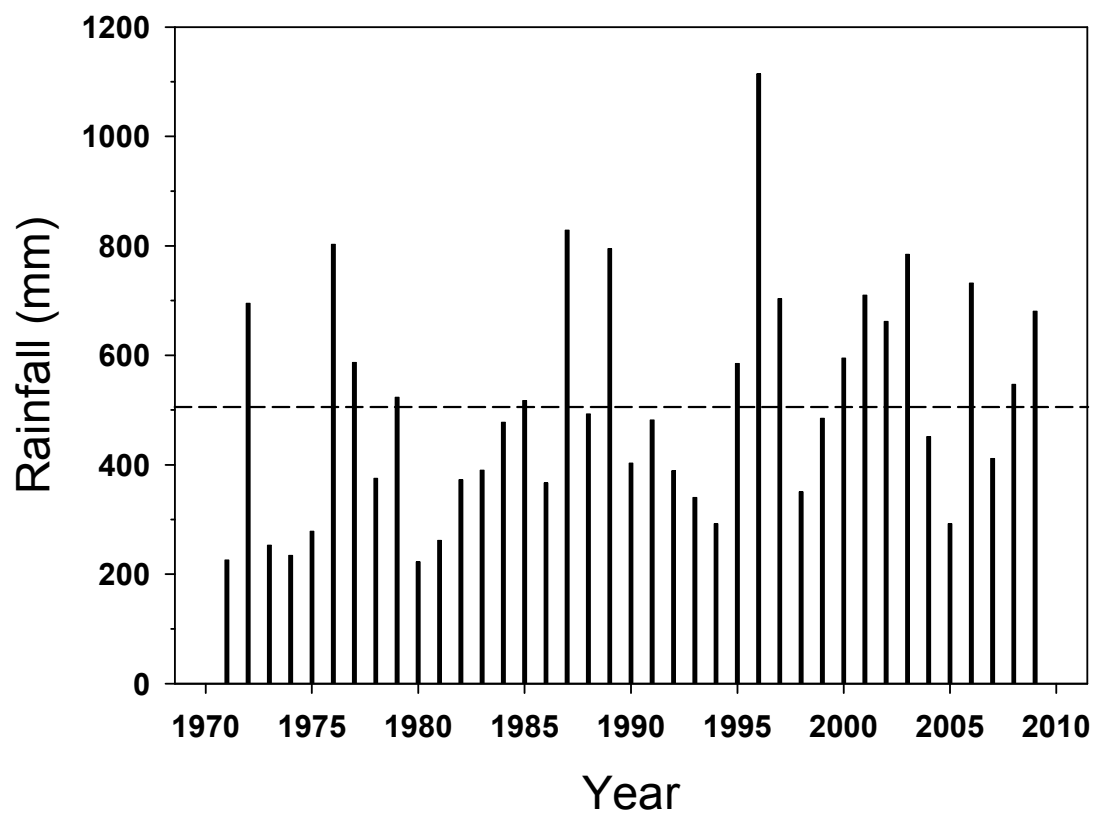

Fig. 2. Annual rainfall collected in the experimental station La Hampa, at $15 \mathrm{~km}$ southwest of Seville $\left(37^{\circ} 17^{\prime} \mathrm{N}, 6^{\circ} 3^{\prime} \mathrm{W}\right)$. The dashed line is the average $(501 \mathrm{~mm})$ for the considered period. 


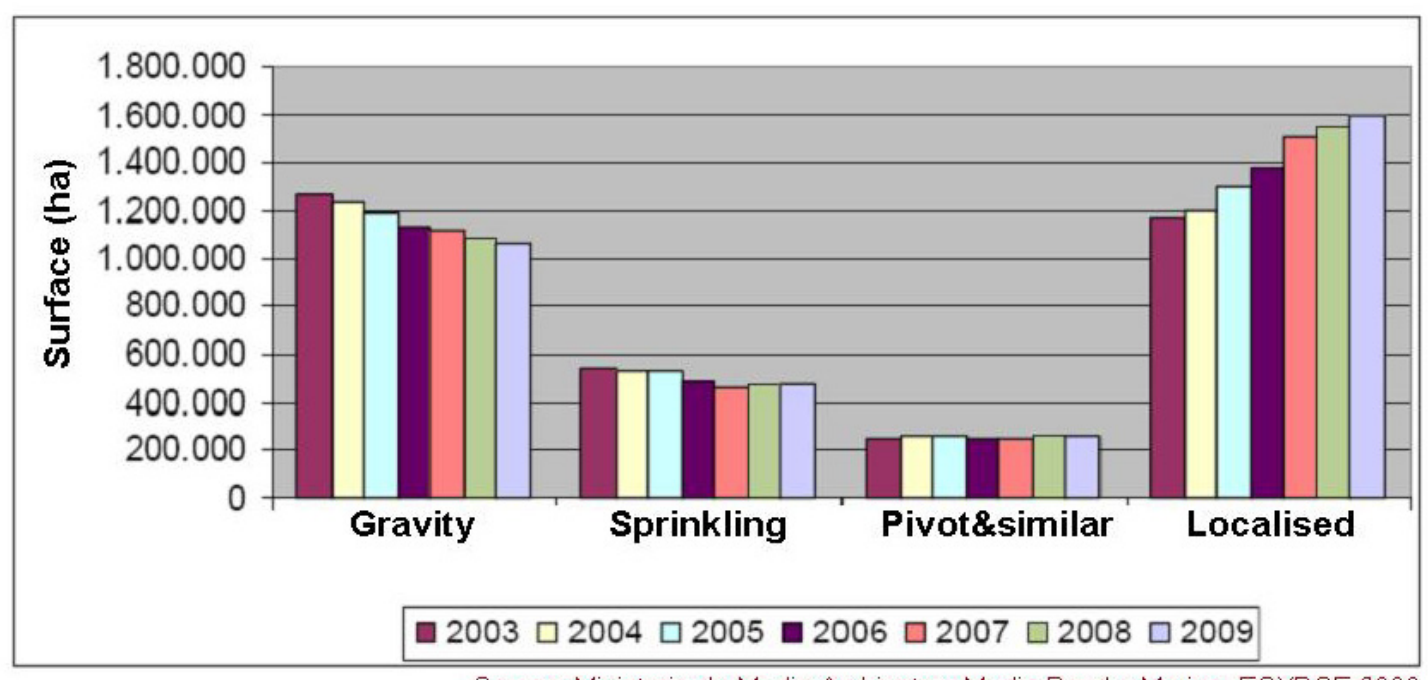

Source: Ministerio de Medio Ambiente y Medio Rural y Marino, ESYRCE 2009

Fig. 3. Trends for the use of different irrigation methods in Spain, for the 2003-2009 period.

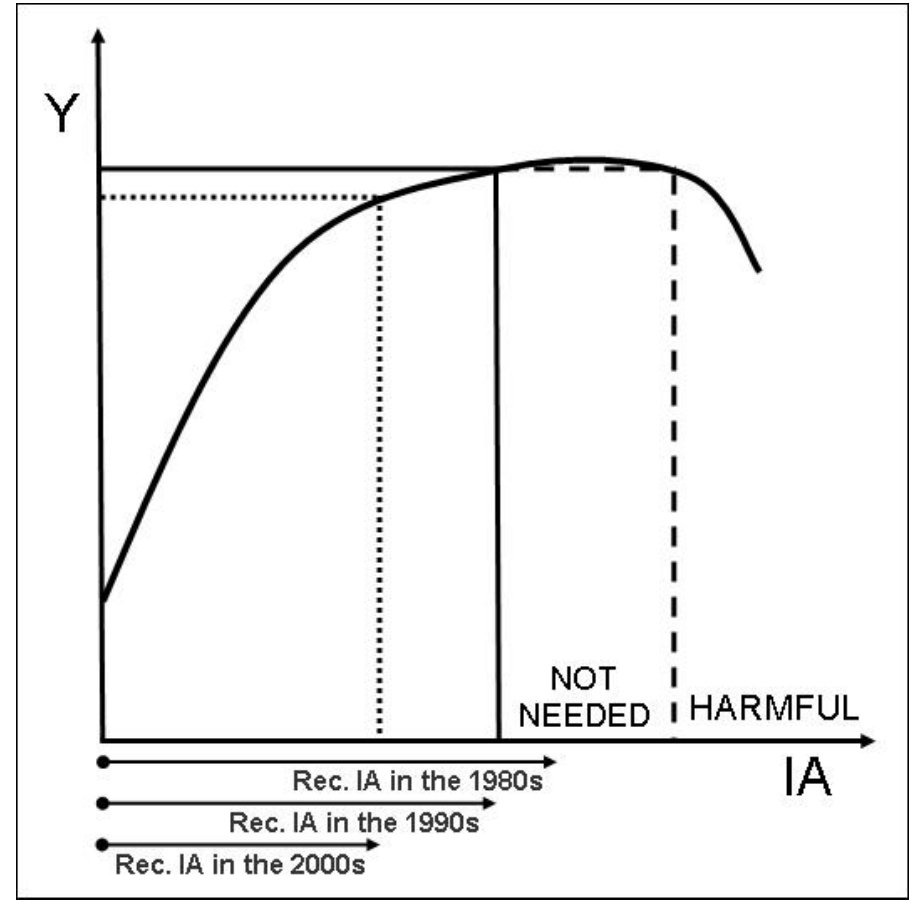

Fig. 4. Time course of the recommended (Rec.) irrigation amount (IA) in the last three decades. $\mathrm{Y}=$ yield. 
